\title{
FAKTOR-FAKTOR YANG MEMPENGARUHI KETIDAKTEPATAN KODE PADA PERSALINAN SECTIO CAESAREA DI RUMAH SAKIT UMUM IMELDA PEKERJA INDONESIA MEDAN TAHUN 2018
}

\author{
1. Erlindai; ${ }^{2}$ Auliya Indriani \\ 1. Dosen APIKES Imelda. Jalan Bilal Nomor 52 Medan, ${ }^{2 \cdot}$ Alumni APIKES Imelda \\ E-mail: ${ }^{1 .}$ erlindaipurba@gmail.com \\ 2. indrianiauliva22@gmail.com
}

\begin{abstract}
ABSTRAK
Salah satu kompetensi perekam medis yaitu perekam medis diharuskan mampu mengklasifikasi dan kodefikasi penyakit. Masih rendahnya persentase ketidaktepatan kode dapat menyebabkan berbagai dampak negatif diantaranya penghitungan berbagai angka statistik rumah sakit akan salah, kualitas laporan yang akan digunakan untuk evaluasi pelayanan akan tidak sinkron, selain itu perencanaan dan pengelolaan rumah sakit, dan kepentingan riset klinik akan mengalami kendala.Tujuan penelitian ini untuk mengetahui faktorfaktor yang mempengaruhi ketidaktepatan kode pada persalinan sectio caesarea di Rumah Sakit Umum (RSU) Imelda Pekerja Indonesia (IPI) Medan. Jenis penelitian ini adalah penelitian kuantitatif dengan pendekatan deskriptif yang dilakukan pada tanggal 30 juni 2018 dengan sampel seluruh populasi 31 petugas rekam medis. Penelitian dilakukan menggunakan aplikasi komputer uji chi square $\left(X^{2}\right)$ dengan kemaknaan 95\% $(\alpha=0.05 \%)$. Hasil penelitian ini ditemukan petugas mengkode dengan tepat sebanyak 10 petugas (32.3\%) dan yang tidak tepat sebanyak 21 petugas (67.7\%). Hasil uji bivariate menunjukan adanya hubungan variabel karakterisik pelatihan, pengetahuan, sikap, kelengkapan dokumen rekam medis, sarana dan prasarana dengan ketidaktepatan kode pada persalinan sectio caesarea di RSU IPI Medan dengan $(p<0.05)$. Diharapkan rumah sakit memeberi kesempatan para petugas rekam medis pelatihan secara berkesinambungan, serta mengevaluasi kelengkapan dokumen rekam medis.
\end{abstract}

Kata Kunci: Ketidaktepatan Kode, Petugas Rekam Medis

\section{PENDAHULUAN}

Rumah Sakit merupakan institusi pelayanan kesehatan yang menyelenggarakan pelayanan kesehatan perorangan secara paripurna yang menyediakan pelayanan rawat inap, rawat jalan, dan gawat darurat. Pelayanan kesehatan yang paripurna merupakan pelayanan lengkap dan sempurna yang harus diberikan oleh pelayanan kesehatan dalam rangka meningkatkan derajat kesehatan masyarakat yang bermutu. Dalam sebuah institusi kesehatan, ada beberapa stakeholder yang bertanggung jawab terhadap mutu layanan kesehatan diantaranya adalah bagian rekam medis (PMK Nomor 56 Tahun 2014).

Kompetensi perekam medis yaitu perekam medis diharuskan mampu melakukan tugas dalam memberikan pelayanan rekam medis dan informasi kesehatan yang bermutu tinggi dengan memperhatikan beberapa kompetensi, salah satunya klasifikasi dan kode klasifikasi penyakit. yang didalamnya dijelaskan bahwasannya seorang petugas rekam medis harus mampu menentukan kode dianosis pasien sesuai petunjuk dan peraturan pada pedoman buku ICD yang berlaku, serta 
mampu mengklasifikasikan data kode diagnosis yang akurat bagi kepentingan informasi morbiditas (Rustiyanto, 2009).

Pengkodeaan adalah prosedur pemberian kode dengan menggunakan huruf dan angka (Hatta, 2012). Pengkodean dengan ICD digunakan untuk mengindeks pencatatan penyakit, masukan bagi sistem pelaporan, bahan, penagihan pembayaran biaya pelayanan, dan untuk penelitian epidemologi dan klinis (Hatta, 2014). Ketepatan coding sangat tergantung pada dokter sebagai penentu diagnosa dan petugas rekam medis sebagai pemeriksa kelengkapannya. Ketepatan pengisian kode diagnosis pada dokumen rekam medis harus dilakukan karena apabila kode diagnosis tidak tepat/tidak sesuai dengan ICD-10 maka dapat menyebabkan turunnya mutu pelayanan di rumah sakit serta mempengaruhi data, informasi laporan, dan ketepatan tarif INACBG's yang pada saat ini digunakan sebagai metode pembayaran untuk pelayanan pasien. Tarif pelayanan kesehatan yang rendah tentunya akan merugikan pihak rumah sakit, sebaliknya tarif pelayanan kesehatan yang tinggi terkesan rumah sakit diuntungkan dari perbedaan tarif tersebut sehingga merugikan pihak penyelenggara jaminan kesehatan maupun pasien.

Terkait dengan permasalahan kode penyakit dan tindakan, masih terdapat kendala ketepatan koding di Rumah sakit Umum Imelda Pekerja indonesia. Berdasarkan penelitian (Ritonga, 2017) yang berjudul Tinjauan Ketepatan Kode Diagnosa Pada Persalinan Sectio Caesarea di Rumah Sakit Umum (RSU) imelda Pekerja Indonesia (IPI) Medan hasil penelitian dari 55 rekam medis pada persalinan sectio caesarea pemberian kode tepat sebanyak 38 berkas $(69 \%)$, dan kode tidak tepat sebanyak 17 berkas (31\%).

Masih rendahnya persentase ketepatan kode dapat menyebabkan berbagai dampak negatif diantaranya penghitungan berbagai angka statistik rumah sakit akan salah, kualitas laporan yang akan digunakan untuk evaluasi pelayanan akan tidak sinkron, selain itu perencanaan dan pengelolaan rumah sakit, dan kepentingan riset klinik akan mengalami kendala. Masalah lain yang tidak kalah penting akibatnya rendahnya ketepatan kode adalah tentang pembayaran kembali klaim asuransi. Ketepatan kode menjadi prasyarat utama kesesuaian pembayaran kembali klaim. Apabila terjadi kesalahan maka akan berdampak kerugian bagi institusi kesehatan atau pasien itu sendiri.

Faktor-faktor yang mempengaruhi akurasi koding yaitu tenaga medis, petugas koding, kelengkapan dokumen rekam medis, kebijakan rumah sakit yng dituangkan dalam bentuk surat keputusan (SK) direktur maupun SOP, serta sarana dan prasarananya (Anggraini dkk, 2017). Di RSU IPI Medan pasien untuk persalinan pada ibu melahirkan ada 1876 pada tahun 2017. Untuk ibu dengan persalinan spontan atau normal ada 739 dan ibu dengan persalinan sectio caesarea ada 1137, sectio caesarea termasuk 10 penyakit terbesar yang ada di RSU IPI Medan. Berdasarkan survei awal yang dilakukan peneliti pada 25 berkas rekam medis pada persalinan sectio caesarea di RSU IPI Medan ada 8 berkas $(32 \%)$ dengan pemberian kode tidak tepat dan ada 17 berkas (68\%) dengan pemberian kode tepat. Berdasarkan wawancara kepada petugas hal ini dikarenakan masih adanya kesalahan dalam menentukan penyulit dalam persalinan serta tulisan dokter yang tidak terbaca dan menggunakan singkatan yang sulit di mengerti menjadi kendala dalam manentukan kode yang tepat.

Berdasarkan Uraian di atas maka penulis tertarik untuk melakukan penelitian mengenai "Faktor-Faktor Yang Mempengaruhi Ketidaktepatan Kode Pada Persalinan Sectio Caesarea di RSU IPI Medan Tahun 2018”.

\section{Rumusan Masalah}

Mengingat permasalahan yang ada, maka peneliti tertarik untuk meninjau lebih lanjut mengenai faktor-faktor yang mempengaruhi ketidaktepatan kode pada persalinan sectio caesarea di RSU IPI Medan tahun 2018. 
1. Apakah ada hubungan karakteristi petugas rekam medis dengan ketidaktepatan kode pada persalinan sectio caesarea dengan di RSU IPI Medan?

2. Apakah ada hubungan kelengkapan dokumen rekam medis dengan ketidaktepatan kode pada persalinan sectio caesarea di RSU IPI Medan?

3. Apakah ada hubungan sarana dan prasaran dengan ketidaktepatan kode pada persalinan sectio caesarea di RSU IPI Medan?

\section{Tujuan Penelitian}

Adapun tujuan dari penelitian ini untuk mengetahui faktor-faktor yang mempengaruhi ketidaktepatan kode pada persalinan sectio caesarea di RSU IPI Medan tahun 2018.

\section{Manfaat Penelitian}

1. Bagi Rumah Sakit

Hasil penelitian ini diharapkan bisa menjadi masukan serta pembelajaran dalam pelaksanaan koding di RSU IPI Medan.

2. Bagi Institusi Pendidikan

Penelitian ini dapat digunakan sebagai bahan masukan untuk penelitian selanjutnya sekaligus referensi yang dapat menambah khasanah keilmuan rekam medis mengenai faktor-faktor yang mempengaruhi ketidaktepatan kode pada persalinan sectio caesarea.

3. Bagi Peneliti

Menambah wawasan peneliti tentang faktor-faktor yang mempengaruhi ketidaktepatan kode pada persalinan sectio caesarea

4. Bagi Peneliti Selanjutnya

Sebagai bahan pratinjau lanjutan untuk meghasilkan pengembangan berkelanjutan tentang faktor-faktor yang mempengaruhi ketidaktepatan kode pada persalinan ibu melahirkan di RSU IPI Medan.

\section{METODE}

Penelitian ini dilakukan dengan menggunakan metode penelitian kuantitatif dengan pendekatan deskriptif. Metode yang digunakan cross sectional jenis penelitian ini digunakan untuk mengetahui faktor-faktor yang mempengaruhi ketidaktepatan kode pada persalinan sectio caesarea di RSU IPI Medan.

\section{Waktu dan Tempat Penelitian}

Penelitian dilakukan pada bulan April sampai dengan Juli 2018. Penelitian ini dilakukan di Rumah Sakit Umum (RSU) Imelda Pekerja Indonesia (IPI) Medan yang beralamat di Jl. Bilal No. 24 Pulo Brayan Darat I Medan.

\section{Populasi}

Populasi merupakan keseluruhan sumber data yang diperlukan dalam suatu penelitian (Saryono, 2013). Populasi pada penelitian ini adalah jumlah seluruh petugas rekam medis yang ada di Unit Rekam Medis yang ada di RSU IPI Medan sebanyak 31 orang petugas.

\section{Sampel}

Sampel adalah sebagian atau wakil populasi yang diteliti (Saryono, 2013). Sampel yang digunakan dalam penelitian ini adalah seluruh populasi, yaitu 31 orang petugas rekam medis.

\section{Variabel}

Variabel merupakan ukuran atau ciri yang dimiliki oleh anggota-anggota suatu kelompok yang berbeda dengan yang dimiliki oleh kelompok lain (Saryono, 2013). Adapun variabel dalam penelitian ini adalah petugas koding, kelengkapan dokumen rekam medis, dan sarana prasarananya. 


\section{Definisi Operasional}

Untuk membatasi ruang lingkup atau pengertian variabel-variabel. Tersebut diberi batasan atau definisi operasional (Notoatmodjo, 2012).

Adapun definisi operasional pada penelitian ini sebagai berikut:

Tabel 1. Tabel Defenisi Operasional

\begin{tabular}{|c|c|c|c|c|c|c|}
\hline No & Variabel & Definisi Operasional & $\begin{array}{l}\text { Skala } \\
\text { Ukur }\end{array}$ & Indikator & $\begin{array}{l}\text { Nilai } \\
\text { Ukur }\end{array}$ & Hasil ukur \\
\hline \multirow[t]{6}{*}{1} & Karakteristik & $\begin{array}{l}\text { Karakteristik mencakup } \\
\text { usia, jenis kelamin, masa } \\
\text { kerja, tingkat pendidikan. }\end{array}$ & & & & \\
\hline & a. Umur & $\begin{array}{l}\text { Lama hidup seseorang yang } \\
\text { dihitung sejak lahir hingga } \\
\text { batas terakhir masa } \\
\text { hidupnya. }\end{array}$ & Rasio & & & 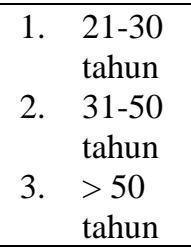 \\
\hline & $\begin{array}{l}\text { b. Jenis } \\
\text { Kelamin }\end{array}$ & $\begin{array}{l}\text { Perbedaan bentuk, sifat dan } \\
\text { fungsi biologis. }\end{array}$ & $\begin{array}{l}\text { Nomin } \\
\text { al }\end{array}$ & & & $\begin{array}{l}\text { 1. Peremp } \\
\text { uan } \\
\text { 2. Laki- } \\
\text { laki } \\
\end{array}$ \\
\hline & c. Pelatihan & $\begin{array}{l}\text { Pembelajaran tentang } \\
\text { pekerjaan yang berkaitan } \\
\text { dengan pengetahuaan, } \\
\text { keahlian dan perilaku. }\end{array}$ & Ordinal & & & $\begin{array}{l}\text { 1. Tidak } \\
\text { ada } \\
\text { 2. Ada }\end{array}$ \\
\hline & $\begin{array}{l}\text { d. Pendidik } \\
\text { an }\end{array}$ & $\begin{array}{l}\text { Jenjang pendidikan formal } \\
\text { yang ditempuh seseorang. }\end{array}$ & Ordinal & & & 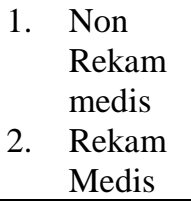 \\
\hline & $\begin{array}{l}\text { e. Pengala } \\
\text { man } \\
\text { Kerja }\end{array}$ & $\begin{array}{l}\text { Proses pembentukan } \\
\text { pengetahuan atau } \\
\text { keterampilan tentang metode } \\
\text { suatu pekerjaan karena } \\
\text { keterlibatan seseorang dalam } \\
\text { pelaksaan tugas pekerjaan. }\end{array}$ & Rasio & & & $\begin{array}{ll}\text { 1. } & \begin{array}{l}0-1 \\
\text { tahun }\end{array} \\
\text { 2. } & \begin{array}{l}2-3 \\
\text { tahun }\end{array} \\
\text { 3. } & \begin{array}{l}4-5 \\
\text { tahun }\end{array} \\
4 . & >5 \\
& \text { tahun } \\
\end{array}$ \\
\hline 2 & Pengetahuan & $\begin{array}{l}\text { Pemahaman dan wawasan } \\
\text { petugas rekam medis tentang } \\
\text { sectio Caesarea dan } \\
\text { menentukan kodenya. }\end{array}$ & Ordinal & 10 soal & $\begin{array}{c}0-3 \\
4-6 \\
7-10\end{array}$ & $\begin{array}{ll}\text { 1. } & \text { Kurang } \\
\text { 2. } & \text { Cukup } \\
\text { 3. } & \text { Baik }\end{array}$ \\
\hline 3 & Sikap & $\begin{array}{l}\text { Respon petugas rekam } \\
\text { medis terhadap pentingnya } \\
\text { pengetahuan serta } \\
\text { menerapkan informasi dan } \\
\text { menentukan kode sectio } \\
\text { caesarea. }\end{array}$ & Ordinal & 10 soal & $\begin{array}{l}10-20 \\
21-30 \\
31-40\end{array}$ & $\begin{array}{l}\text { 1. Kurang } \\
\text { 2. Cukup } \\
\text { 3. } \text { Baik }\end{array}$ \\
\hline 4 & $\begin{array}{l}\text { Kelengkapan } \\
\text { Dokumen } \\
\text { Rekam } \\
\text { Medis } \\
\end{array}$ & $\begin{array}{l}\text { Kelengkapan dokumen } \\
\text { rekam medis secara } \\
\text { kualitatif dan kuantitatif. }\end{array}$ & Ordinal & & & $\begin{array}{l}\text { 1. Tidak } \\
\text { Lengkap } \\
\text { 2. Lengkap }\end{array}$ \\
\hline
\end{tabular}




\begin{tabular}{|c|c|c|c|c|}
\hline 5 & $\begin{array}{l}\text { Sarana dan } \\
\text { Prasarana }\end{array}$ & $\begin{array}{l}\text { Segala sesuatu yang dapat } \\
\text { dipakai sebagai alat dalam } \\
\text { klasifikasi dan kodefikasi } \\
\text { penyakit. }\end{array}$ & Ordinal & $\begin{array}{l}\text { 1. Tidak } \\
\text { Lengkap } \\
\text { 2. Lengkap } \\
\end{array}$ \\
\hline 6 & $\begin{array}{l}\text { Ketidaktepat } \\
\text { an kode pada } \\
\text { persalinan } \\
\text { sectio } \\
\text { caesarea }\end{array}$ & $\begin{array}{l}\text { Kode persalinan sectio } \\
\text { caesarea yang tidak sesuai } \\
\text { dengan kaidah ICD-10 }\end{array}$ & Ordinal & $\begin{array}{l}\text { 1. Tidak } \\
\text { Tepat } \\
\text { 2. Tepat }\end{array}$ \\
\hline
\end{tabular}

\section{Instrumen Penelitian}

Instrumen penelitian adalah alat atu fasilitas yang digunakan oleh peneliti dalam mengumpulkan data agar pekerjaannya lebih mudah dan hasilnya lebih baik (cermat, lengkap, dan sistematis) sehingga lebih mudah diolah (Saryono, 2013). Instrumen penelitian ini adalah angket. Angket adalah suatu cara pengumpulan data atau suatu penelitian mengenai suatu maslah yang umummnya banyak menyangkut kepentingan umum (banyak orang). Angket dilakukan dengan membagikan suatu daftar pertanyaan yang berupa formulir-formulir, diajukan secara tertulis kepada sejumlah subjek untuk mendapatkan tanggapan, informasi, jawaban, dan sebagainya (Notoatmodjo, 2012).

\section{Pengumpulan Data}

Peneliti mengumpulkan data dengan menggunakan angket dengan jumlah pertanyaan sebanyak 10 item. Angket yang digunakan adalah angket tertutup, yaitu angket yang sudah dilengkapi dengan jawaban. Setiap item terdiri dari dua pilihan jawaban menurut skala Guttman. Untuk jawaban ya diberi kode 1 dan jawaban tidak adalah 0. Skor tertinggi adalah $10(10 \mathrm{x} 1)$ dan yang terendah $0(10 \mathrm{x} 0)$ sehingga rentang skor untuk pengeahuan petugas rekam medis 0-10. Katagori tingkat pengetahuan petugas koding menggunakan rumus:

$$
\begin{gathered}
\text { interval }=\frac{\text { nilai tertinggi-nilai terendah }}{\text { kelas }} \\
I=\frac{10-0}{3} \\
I=3,33=3
\end{gathered}
$$

Sehingga di dapat katagori:

1. Baik, jika skor mendapatkan 7-10
2. Cukup, jika mendapatkan skor $4-6$

3. Kurang, jika mendapatkan skor 0-3

Peneliti mengumpulkan data tentang sikap petugas rekam medis dengan menggunakan angket dengan jumlah pertanyaan sebanyak 10 item. Angket yang digunakan adalah angket tertutup, yaitu angket yang sudah dilengkapi dengan jawaban. Setiap item terdiri dari empat pilihan jawaban menurut skala Likert. Untuk jawaban sangat sesuai diberi skor 4, jawaban sesuai diberi skor 3, jawaban tidak sesuai diberi skor 2 dan jawaban tidak sesuai diberi skor 1 .

Skor tertinggi adalah 40(10x4) dan yang terendah 10(10x1) sehingga rentang skor untuk sikap petugas rekam medis 10-40. Katagori tingkat sikap petugas koding menggunakan rumus:

$$
\begin{gathered}
\text { interval }=\frac{\text { nilai tertinggi-nilai terendah }}{\text { kelas }} \\
I=\frac{40-10}{3} \\
I=10
\end{gathered}
$$

Sehingga di dapat katagori:

1. Baik, jika skor mendapatkan 31-40

2. Cukup, jika mendapatkan skor 21-30

3. Kurang, jika mendapatkan skor 10-20

\section{Teknik Pengolahan Data}

Setelah data terkumpul maka dilakukan pengolahan data, data diolah seccara:

1. Editing yaitu dengan melakukan pengecekan isian formulir (angket dan kuisioner) apakah jawaban sudah jelas dan konsisten.

2. Coding yaitu dengan merubah data yang sudah berbentuk huruf menjadi data berbentuk angka. 
3. Entry (Processing) yaitu memasukan jawaban-jawban dari responden dalam bentuk kode (angka atau huruf) kedalam program atau software computer.

4. Tabulasi data merupakan proses pengoolahan data yang dilakukn dengan cara memasukkan data kedalam tabel atau penyajian data dalam bentuk tabel dan daftar untuk memudahkan dalam pengamatan dan evaluasi.

5. Cleaning yaitu melakukan pembersihan data dengan cara memeriksa data-data yang telah ditentukan sebelumnya.

\section{Analisis Data penelitian}

Data akan dianalisis dengan menggunaka

n statistik deskriptif yaitu teknik sisa data yang menggambarkan situasi objek penelitian ini dilakukan dengan bantuan komputer.

1. Analisis Univariat, dalam analisis univari at ini data dihitung untuk masing-masing variabel disajikan dalam tabel distribusi frekuensi.

2. Analisis Bivariat, untuk mengetahui hubungan ketidaktepatan kode pada persalinan sectio caesarea terhadap petugas koding, kelengkappan dokumen rekam medis, dan sarana prasarananya. Peneliti mengguakan teknik analisis data yaitu uji Chi-Square $\left(\mathrm{X}^{2}\right)$ menggunakan aplikasi pada komputer dengan tingkat kemaknaan $95 \% \quad(\alpha=0,05)$, penerimaan atau penolakan hipotesis adalah sebagai berikut:

a. Ho diterima dan Ha ditolak jika nilai $X^{2}$ hitung $>X^{2}$ tabel atau nilai $p>0,05$ berarti tidak ada hubungan ketidaktepa tan kode pada persalinan sectio caesarea terhadap petugas rekam medis, kelengkappan dokumen rekam medis, dan sarana prasarananya.

b. Ho ditolak dan Ha diterima jika nilai $X^{2}$ hitung $>X^{2}$ tabel atau nilai $p<0,05$ ada hubungan ketidaktepatan kode pada persalinan sectio caesarea terhadap petugas rekam medis, keleng kappan dokumen rekam medis, dan sarana prasarananya

\section{HASIL}

Berdasarkan penelitian yang dilakukan penulis mengenai "Faktor-Faktor Yang Mempengaruhi Ketidaktepatan Kode Pada Persalinan Sectio Caesarea di RSU IPI Medan Tahun 2018" dari 31 petugas rekam medis.

\section{Analisis Univariat}

Tabel 2. Distribusi Frekuensi Berdasarkan Umur Petugas Rekam Medis di RSU IPI Medan

\begin{tabular}{cccc}
\hline No & Umur & Frekuensi & $\begin{array}{c}\text { Persentase } \\
(\boldsymbol{\%})\end{array}$ \\
\hline 1 & $21-30$ Tahun & 22 & 71 \\
\hline 2 & $31-40$ Tahun & 9 & 29 \\
\hline & Total & $\mathbf{3 1}$ & $\mathbf{1 0 0}$ \\
\hline
\end{tabular}

Tabel 2 menunjukkan bahwa distribusi umur petugas rekam medis dari 31 responden yang diteliti yang berumur 21-30 tahun lebih banyak dibanding petugas rekam medis yang berumur 31-40 tahun. Petugas rekam medis berumur 21-30 tahun sebanyak 22 responden $(71 \%)$, dan petugas rekam medis berumur 3140 tahun sebanyak 9 responden (29\%).

Tabel 3. Distribusi Frekuensi Berdasarkan Jenis Kelamin Petugas Rekam Medis di RSU IPI Medan

\begin{tabular}{cccc}
\hline No & Jenis Kelamin & Frekuensi & $\begin{array}{c}\text { Persentase } \\
(\mathbf{\%})\end{array}$ \\
\hline 1 & Perempuan & 21 & 67.7 \\
\hline 2 & Laki-Laki & 10 & 32.3 \\
\hline & Total & $\mathbf{3 1}$ & $\mathbf{1 0 0}$ \\
\hline
\end{tabular}

Tabel 3 menunjukkan bahwa distribusi jenis kelamin petugas rekam medis dari 31 responden yang telah diteliti, petugas rekam medis yang berjenis kelamin perempuan lebih banyak dari petugas rekam medis yang berjenis kelamin laki-laki. Petugas rekam medis yang berjenis kelamin perempuan sebanyak 21 responden (67.7\%), dan laki-laki sebanyak 10 responden (32.3\%).

Tabel 4. Distribusi Frekuensi Berdasarkan Pelatihan Petugas Rekam Medis di RSU IPI Medan 


\begin{tabular}{cccc}
\hline No & Pelatihan & Frekuensi & $\begin{array}{c}\text { Persentase } \\
(\boldsymbol{\%})\end{array}$ \\
\hline 1 & Tidak Ada & 18 & 58.1 \\
\hline 2 & Ada & 13 & 41.9 \\
\hline & Total & $\mathbf{3 1}$ & $\mathbf{1 0 0}$ \\
\hline
\end{tabular}

Tabel 4 menunjukkan bahwa distribusi pelatihan petugas rekam medis dari 31 respon den yang telah diteliti, petugas rekam medis yang tidak ada mengikuti pelatihan lebih banyak dari petugas rekam medis yang ada mengikuti pelatihan. Petugas rekam medis yang tidak ada mengikuti pelatihan sebanyak 18 responden $(58.1 \%)$, dan yang ada mengikuti pelatihan sebanyak 13 responden $(41.9 \%)$.

Tabel 5. Distribusi Frekuensi Berdasarkan Pendidikan Petugas Rekam Medis di RSU IPI Medan

\begin{tabular}{cccc}
\hline No & Pendidikan & Frekuensi & $\begin{array}{c}\text { Persentase } \\
(\boldsymbol{\%})\end{array}$ \\
\hline 1 & $\begin{array}{c}\text { Non Rekam } \\
\text { Medis }\end{array}$ & 20 & 64.5 \\
\hline 2 & Rekam Medis & 11 & 35.5 \\
\hline & Total & $\mathbf{3 1}$ & $\mathbf{1 0 0}$ \\
\hline
\end{tabular}

Tabel 5 menunjukkan bahwa distribusi pendidikan petugas rekam medis dari 31 responden yang telah diteliti, petugas rekam medis dengan latar pendidikan non rekam medis lebih banyak dari petugas rekam medis dengan latar belakang pendidikan rekam medis. Petugas rekam medis dengan latar belakang non rekam medis sebanyak 20 responden $(64.5 \%)$, dan petugas rekam medis dengan latar belakang pendidikan rekam medis sebanyak 11 responden $(35.5 \%)$.

Tabel 6. Distribusi Frekuensi Berdasarkan Pengalaman Kerja Petugas Rekam Medis di RSU IPI Medan

\begin{tabular}{cccc}
\hline No & $\begin{array}{c}\text { Pengalaman } \\
\text { Kerja }\end{array}$ & Frekuensi & $\begin{array}{c}\text { Persentase } \\
(\boldsymbol{\%})\end{array}$ \\
\hline 1 & $0-1$ tahun & 6 & 19.35 \\
\hline 2 & $2-3$ tahun & 12 & 38.7 \\
\hline 3 & $4-5$ tahun & 7 & 22.6 \\
\hline 4 & $>5$ tahun & 6 & 19.35 \\
\hline & Total & $\mathbf{3 1}$ & $\mathbf{1 0 0}$ \\
\hline
\end{tabular}

Tabel 6 menunjukkan bahwa distribusi pengalaman kerja petugas rekam medis dari
31 responden yang telah diteliti, petugas rekam medis dengan pengalaman kerja 2-3 tahun lebih banyak dari petugas rekam medis dengan pengalaman kerja $0-1$ tahun dan $>5$ tahun. Petugas rekam medis dengan pengalaman kerja 2-3 tahun sebanyak 12 responden $(38.7 \%)$, dan petugas rekam medis dengan pengalaman kerja $0-1$ tahun dan $>5$ tahun sebanyak 6 responden $(19.35 \%)$.

Tabel 7. Distribusi Frekuensi Berdasarkan Pengetahuan Petugas Rekam Medis di RSU IPI Medan

\begin{tabular}{cccc}
\hline No & Pengetahuan & Frekuensi & $\begin{array}{c}\text { Persentase } \\
(\%)\end{array}$ \\
\hline 1 & Kurang & 13 & 41.9 \\
\hline 2 & Cukup & 12 & 38.7 \\
\hline 3 & Baik & 6 & 19.4 \\
\hline & Total & $\mathbf{3 1}$ & $\mathbf{1 0 0}$ \\
\hline
\end{tabular}

Tabel 7 menunjukkan bahwa distribusi pengetahuan petugas rekam medis dari 31 responden yang telah diteliti, petugas rekam medis yang berpengetahuan kurang lebih banyak dari petugas rekam medis yang berpengetahuan baik. Petugas rekam medis yang berpengetahuan kurang sebanyak 13 responden (41.9\%), dan petugas yang berpengetahuan baik sebanyak 6 responden (19.4\%).

Tabel 8. Distribusi Frekuensi Berdasarkan Sikap Petugas Rekam Medis di RSU IPI Medan

\begin{tabular}{cccc}
\hline No & Sikap & Frekuensi & $\begin{array}{c}\text { Persentase } \\
(\mathbf{\%})\end{array}$ \\
\hline 1 & Kurang & 12 & 38.7 \\
\hline 2 & Cukup & 13 & 41.9 \\
\hline 3 & Baik & 6 & 19.4 \\
\hline & Total & $\mathbf{3 1}$ & $\mathbf{1 0 0}$
\end{tabular}

Tabel 8 menunjukkan bahwa distribusi sikap petugas rekam medis dari 31 responden yang telah diteliti, petugas rekam medis yang bersikap cukup lebih banyak dari petugas rekam medis yang bersikap baik. Petugas rekam medis yang bersikap cukup sebanyak 13 responden $(41.9 \%)$, dan petugas yang bersikap baik sebanyak 6 responden $(19.4 \%)$. 
Tabel 9. Distribusi Frekuensi Berdasarkan Kelengkapan Dokumen Rekam Medis di RSU IPI Medan

\begin{tabular}{cccc}
\hline No & $\begin{array}{c}\text { Kelengkapan } \\
\text { Dokumen } \\
\text { Rekam Medis }\end{array}$ & Frekuensi & $\begin{array}{c}\text { Persentase } \\
(\boldsymbol{\%})\end{array}$ \\
\hline 1 & Tidak Lengkap & 14 & 45.2 \\
2 & Lengkap & 17 & 54.8 \\
\hline & Total & $\mathbf{3 1}$ & $\mathbf{1 0 0}$ \\
\hline
\end{tabular}

Tabel 9 menunjukkan bahwa distribusi kelengkapan dokumen rekam medis dari 31 responden yang telah diteliti, dokumen rekam medis yang lengkap lebih banyak dari dokumen rekam medis yang tidak lengkap. Dokumen rekam medis yang lengkap sebanyak 17 berkas (54.8\%), dan dokumen rekam medis yang tidak lengkap sebanyak 14 berkas $(45.2 \%)$.

Tabel 10. Distribusi Frekuensi Berdasarkan Sarana dan Prasarana di RSU IPI Medan

\begin{tabular}{cccc}
\hline No & $\begin{array}{c}\text { Sarana dan } \\
\text { Prasarana }\end{array}$ & Frekuensi & $\begin{array}{c}\text { Persentase } \\
(\boldsymbol{\%})\end{array}$ \\
\hline 1 & Tidak Lengkap & 13 & 41.9 \\
\hline 2 & Lengkap & 18 & 58.1 \\
\hline & Total & $\mathbf{3 1}$ & $\mathbf{1 0 0}$ \\
\hline
\end{tabular}

Tabel 10 menunjukkan bahwa distribusi sarana dan prasarana dari 31 responden yang telah diteliti, sarana dan prasarana yang lengkap lebih banyak dari sarana dan prasaran a yang tidak lengkap. Sarana dan prasarana yang lengkap sebanyak 18 berkas (58.1\%), dan sarana prasarana yang tidak lengkap sebanyak 13 berkas (41.9\%).

Tabel 11. Distribusi Frekuensi Berdasarkan Ketidaktepatan Kode Pada Persalinan Sectio Caesarea di RSU IPI Medan

\begin{tabular}{cccc}
\hline No & $\begin{array}{c}\text { Ketidaktepatan } \\
\text { Kode pada } \\
\text { Persalianan } \\
\text { Sectio Caesrae }\end{array}$ & Frekuensi & $\begin{array}{c}\text { Persentase } \\
(\mathbf{\%})\end{array}$ \\
\hline 1 & Tidak Tepat & 21 & 67.7 \\
\hline 2 & Tepat & 10 & 32.3 \\
\hline & Total & $\mathbf{3 1}$ & $\mathbf{1 0 0}$ \\
\hline
\end{tabular}

Tabel 11 menunjukkan bahwa distribusi ketidaktepatan kode pada persalinan sectio caesarea dari 31 responden yang telah diteliti, petugas rekam medis yang mengkode tidak tepat lebih banyak dari petugas rekam medis yang mengkode dengan tepat. Petugas rekam medis yang mengkode tidak tepat sebanyak 21 petugas $(67.7 \%)$, dan petugas rekam medis yang megkode dengan tepat sebanyak 10 petugas $(32.3 \%)$.

\section{Analisis Bivariat}

Tabel 12. Hubungan Faktor Umur dengan Ketidaktepatan Kode Pada Persalinan Sectio Caesarea di RSU IPI Medan

\begin{tabular}{|c|c|c|c|c|c|c|c|c|}
\hline \multirow{3}{*}{$\begin{array}{l}\mathbf{N} \\
\mathbf{o}\end{array}$} & \multirow{3}{*}{$\begin{array}{l}\text { Umu } \\
\mathbf{r}\end{array}$} & \multicolumn{6}{|c|}{$\begin{array}{l}\text { Ketidaktepatan Kode Pada } \\
\text { Persalinan Sectio Caesaraea }\end{array}$} & \\
\hline & & \multicolumn{2}{|c|}{$\begin{array}{l}\text { Tidak } \\
\text { Tepat }\end{array}$} & \multicolumn{2}{|c|}{ Tepat } & \multicolumn{2}{|c|}{ Total } & $P$ \\
\hline & & $F$ & $\%$ & $\boldsymbol{F}$ & $\%$ & $\boldsymbol{F}$ & $\%$ & \\
\hline 1 & $\begin{array}{l}21-30 \\
\text { tahun }\end{array}$ & $\begin{array}{l}1 \\
5 \\
\end{array}$ & $\begin{array}{l}48 . \\
4\end{array}$ & 7 & $\begin{array}{l}22 \\
6\end{array}$ & $\begin{array}{l}2 \\
2 \\
\end{array}$ & 71 & \\
\hline 2 & $\begin{array}{l}31-40 \\
\text { tahun }\end{array}$ & 6 & $\begin{array}{l}19 . \\
3\end{array}$ & 3 & 9.7 & 9 & 29 & 1 \\
\hline \multicolumn{2}{|c|}{ Total } & $\begin{array}{l}2 \\
1\end{array}$ & $\begin{array}{l}67 . \\
7\end{array}$ & $\begin{array}{l}1 \\
\mathbf{0}\end{array}$ & $\begin{array}{l}32 \\
3\end{array}$ & $\begin{array}{l}3 \\
1\end{array}$ & $\begin{array}{l}10 \\
0\end{array}$ & \\
\hline
\end{tabular}

Tabel 12 menunjukkan hasil uji statistik tentang pengaruh umur petugas rekam medis dengan ketidaktepatan kode pada persalinan sectio caesarea. Diperoleh $\mathrm{p}=1>0.05$ sehingga Ho diterima artinya tidak ada hubungan antara umur petugas rekam medis dengan ketidaktepatan kode pada persalinan sectio caesarea di RSU IPI.

Tabel 13. Hubungan Faktor Jenis Kelamin dengan Ketidaktepatan Kode Pada Persalinan Sectio Caesarea di RSU IPI Medan

\begin{tabular}{|c|c|c|c|c|c|c|c|c|}
\hline \multirow{4}{*}{$\begin{array}{l}\mathbf{N} \\
\mathbf{0}\end{array}$} & \multirow{4}{*}{$\begin{array}{l}\text { Jenis } \\
\text { Kelami } \\
\quad \text { n }\end{array}$} & \multirow{2}{*}{\multicolumn{4}{|c|}{$\begin{array}{l}\text { Ketidaktepatan } \\
\text { Pada Persalinan } \\
\text { Caesaraea }\end{array}$}} & \multirow{2}{*}{\multicolumn{2}{|c|}{$\begin{array}{l}\text { Kode } \\
\text { Sectio }\end{array}$}} & \multirow{4}{*}{$\boldsymbol{P}$} \\
\hline & & & & & & & & \\
\hline & & \multicolumn{2}{|c|}{$\begin{array}{l}\text { Tidak } \\
\text { Tepat }\end{array}$} & \multicolumn{2}{|c|}{ Tepat } & \multicolumn{2}{|c|}{ Total } & \\
\hline & & $F$ & $\%$ & $F$ & $\%$ & $F$ & $\%$ & \\
\hline \multirow{2}{*}{1} & Peremp & 1 & 48. & 6 & 19. & 2 & 67. & \multirow{6}{*}{$\begin{array}{l}0.6 \\
85\end{array}$} \\
\hline & uan & 5 & 4 & 0 & 3 & 1 & 7 & \\
\hline 2 & Laki- & 6 & 19. & 4 & 13 & 1 & 32. & \\
\hline 2 & Laki & & 3 & 4 & 13 & 0 & 3 & \\
\hline & \multirow[t]{2}{*}{ Total } & 2 & 67. & 1 & 32. & 3 & 10 & \\
\hline & & 1 & 7 & $\mathbf{0}$ & 3 & 1 & 0 & \\
\hline
\end{tabular}

Tabel 13 menunjukkan hasil uji statistik tentang pengaruh jenis kelamin petugas rekam medis dengan ketidaktepatan kode pada 
persalinan sectio caesarea. Diperoleh $\mathrm{p}=0.685>0.05$ sehingga Ho diterima artinya tidak ada hubungan antara jenis kelamin petugas rekam medis dengan ketidaktepatan kode pada persalinan sectio caesarea di RSU IPI.

Tabel 14. Hubungan Faktor Pelatihan dengan Ketidaktepatan Kode Pada Persalinan Sectio Caesarea di RSU IPI Medan

\begin{tabular}{|c|c|c|c|c|c|c|c|c|}
\hline \multirow{3}{*}{$\begin{array}{l}\mathbf{N} \\
\mathbf{o}\end{array}$} & \multirow{3}{*}{$\begin{array}{c}\text { Pelatih } \\
\text { an }\end{array}$} & \multicolumn{6}{|c|}{$\begin{array}{c}\text { Ketidaktepatan Kode Pada } \\
\text { Persalinan Sectio } \\
\text { Caesaraea }\end{array}$} & \multirow{3}{*}{$P$} \\
\hline & & \multicolumn{2}{|c|}{$\begin{array}{l}\text { Tidak } \\
\text { Tepat }\end{array}$} & \multicolumn{2}{|c|}{ Tepat } & \multicolumn{2}{|c|}{ Total } & \\
\hline & & $F$ & $\%$ & $F$ & $\%$ & $F$ & $\%$ & \\
\hline \multirow{2}{*}{1} & Tidak & 1 & 51. & & & 2 & 57. & \multirow{4}{*}{$\begin{array}{c}0 . \\
00 \\
6\end{array}$} \\
\hline & Ada & 6 & 6 & 2 & 6.5 & 1 & 1 & \\
\hline 2 & Ada & 5 & $\begin{array}{c}16 . \\
1 \\
\end{array}$ & 8 & $\begin{array}{c}25 . \\
8 \\
\end{array}$ & $\begin{array}{l}1 \\
0 \\
\end{array}$ & $\begin{array}{c}41 . \\
9\end{array}$ & \\
\hline \multicolumn{2}{|c|}{ Total } & & $\begin{array}{c}67 . \\
7\end{array}$ & $\begin{array}{l}1 \\
0\end{array}$ & $\begin{array}{c}32 . \\
32\end{array}$ & $\begin{array}{l}3 \\
1\end{array}$ & $\begin{array}{c}10 \\
0\end{array}$ & \\
\hline
\end{tabular}

Tabel 14 menunjukkan hasil uji statistik tentang pengaruh pelatihan petugas rekam medis dengan ketidaktepatan kode pada persalinan section caesarea. Diperoleh $\mathrm{p}=0.00$ $6<0.05$ sehingga Ho ditolak artinya ada hubungan antara pelatihan petugas rekam medis dengan ketidaktepatan kode pada persalinan sectio caesarea di RSU IPI.

Tabel 15. Hubungan Faktor Pendidikan dengan Ketidaktepatan Kode Pada Persalinan Sectio Caesarea di RSU IPI Medan

\begin{tabular}{|c|c|c|c|c|c|c|c|c|}
\hline \multirow{3}{*}{$\begin{array}{l}\mathbf{N} \\
\mathbf{0}\end{array}$} & \multirow{3}{*}{$\begin{array}{c}\text { Pendidi } \\
\text { kan }\end{array}$} & \multicolumn{6}{|c|}{$\begin{array}{c}\text { Ketidaktepatan Kode } \\
\text { Pada Persalinan Sectio } \\
\text { Caesaraea }\end{array}$} & \multirow{3}{*}{$\boldsymbol{P}$} \\
\hline & & \multicolumn{2}{|c|}{$\begin{array}{l}\text { Tidak } \\
\text { Tepat }\end{array}$} & \multicolumn{2}{|c|}{ Tepat } & \multicolumn{2}{|c|}{ Total } & \\
\hline & & $F$ & $\%$ & $F$ & $\%$ & $F$ & $\%$ & \\
\hline 1 & $\begin{array}{l}\text { Non } \\
\text { Rekam } \\
\text { medis }\end{array}$ & $\begin{array}{l}1 \\
6\end{array}$ & $\begin{array}{c}51 . \\
6\end{array}$ & 4 & $\begin{array}{r}12 \\
9\end{array}$ & $\begin{array}{l}2 \\
0\end{array}$ & $\begin{array}{c}64 . \\
6\end{array}$ & \\
\hline 2 & $\begin{array}{l}\text { Rekam } \\
\text { Medis }\end{array}$ & 5 & $\begin{array}{c}16 . \\
1 \\
\end{array}$ & 6 & $\begin{array}{r}19 \\
4 \\
\end{array}$ & $\begin{array}{l}1 \\
1 \\
\end{array}$ & $\begin{array}{r}35 \\
4 \\
\end{array}$ & 0.1 \\
\hline & Total & $\begin{array}{l}2 \\
1\end{array}$ & $\begin{array}{c}67 . \\
7 \\
\end{array}$ & $\begin{array}{l}1 \\
0\end{array}$ & $\begin{array}{r}32 \\
3 \\
\end{array}$ & $\begin{array}{l}3 \\
1\end{array}$ & $\begin{array}{c}10 \\
0\end{array}$ & \\
\hline
\end{tabular}

Tabel 15 menunjukkan hasil uji statistik tentang pengaruh pendidikan petugas rekam medis dengan ketidaktepatan kode pada persalinan sectio caesarea. Diperoleh $\mathrm{p}=0.106>0.05$ sehingga Ho diterima artinya tidak ada hubungan antara pendidikan petugas rekam medis dengan ketidaktepatan kode pada persalinan sectio caesarea di RSU IPI.

Tabel 16. Hubungan Faktor Pengalaman Kerja dengan Ketidaktepatan Kode Pada Persalinan Sectio Caesarea

\begin{tabular}{|c|c|c|c|c|c|c|c|c|}
\hline \multirow{3}{*}{$\begin{array}{l}\mathbf{N} \\
\mathbf{0}\end{array}$} & \multirow{3}{*}{$\begin{array}{l}\text { Pengala } \\
\text { man } \\
\text { Kerja }\end{array}$} & \multicolumn{6}{|c|}{$\begin{array}{c}\text { Ketidaktepatan Kode } \\
\text { Pada Persalinan Sectio } \\
\text { Caesaraea }\end{array}$} & \multirow{3}{*}{$\boldsymbol{P}$} \\
\hline & & \multicolumn{2}{|c|}{$\begin{array}{l}\text { Tidak } \\
\text { Tepat }\end{array}$} & \multicolumn{2}{|c|}{ Tepat } & \multicolumn{2}{|c|}{ Total } & \\
\hline & & $F$ & $\%$ & $F$ & $\%$ & $F$ & $\%$ & \\
\hline 1 & $\begin{array}{c}0-1 \\
\text { tahun }\end{array}$ & 5 & $\begin{array}{l}16 \\
.1\end{array}$ & 1 & $\begin{array}{l}3 . \\
2\end{array}$ & 6 & $\begin{array}{l}19 \\
.3\end{array}$ & \\
\hline 2 & $\begin{array}{c}2-3 \\
\text { tahun }\end{array}$ & 9 & 29 & 3 & $\begin{array}{l}9 . \\
7\end{array}$ & $\begin{array}{l}1 \\
2\end{array}$ & $\begin{array}{l}38 \\
.7\end{array}$ & \\
\hline 3 & $\begin{array}{c}4-5 \\
\text { tahun }\end{array}$ & 5 & $\begin{array}{l}16 \\
.1\end{array}$ & 2 & $\begin{array}{l}6 . \\
5\end{array}$ & 7 & $\begin{array}{r}22 \\
.6 \\
\end{array}$ & $\begin{array}{l}0.3 \\
26\end{array}$ \\
\hline 4 & $>5$ tahun & 2 & $\begin{array}{l}6 . \\
5\end{array}$ & 4 & $\begin{array}{l}12 \\
.9\end{array}$ & 6 & $\begin{array}{l}19 \\
.4\end{array}$ & \\
\hline & Total & $\begin{array}{l}2 \\
1\end{array}$ & $\begin{array}{r}67 \\
.7\end{array}$ & $\begin{array}{l}1 \\
0\end{array}$ & $\begin{array}{r}32 \\
.3\end{array}$ & $\begin{array}{l}3 \\
1\end{array}$ & $\begin{array}{c}10 \\
0\end{array}$ & \\
\hline
\end{tabular}

Tabel 16 menunjukkan hasil uji statistik tentang pengaruh pengalaman kerja petugas rekam medis dengan ketidaktepatan kode pada persalinan section caesarea. Diperoleh $\mathrm{p}=0.32$ 6>0.05 sehingga Ho diterima artinya tidak ada hubungan antara pengalaman petugas rekam medis dengan ketidaktepatan kode pada persalinan sectio caesarea di RSU IPI.

Tabel 17. Hubungan Faktor Pengetahuan dengan Ketidaktepatan Kode Pada Persalinan Sectio Caesarea di RSU IPI Medan

\begin{tabular}{|c|c|c|c|c|c|c|c|c|}
\hline \multirow{3}{*}{$\begin{array}{l}\mathbf{N} \\
\mathbf{o}\end{array}$} & \multirow{3}{*}{$\begin{array}{l}\text { Penget } \\
\text { ahuan }\end{array}$} & \multicolumn{6}{|c|}{$\begin{array}{l}\text { Ketidaktepatan Kode Pada } \\
\text { Persalinan Sectio Caesaraea }\end{array}$} & \multirow{3}{*}{$P$} \\
\hline & & \multicolumn{2}{|c|}{$\begin{array}{l}\text { Tidak } \\
\text { Tepat }\end{array}$} & \multicolumn{2}{|c|}{ Tepat } & \multicolumn{2}{|c|}{ Total } & \\
\hline & & $F$ & $\%$ & $F$ & $\%$ & $F$ & $\%$ & \\
\hline 1 & Kurang & $\begin{array}{l}1 \\
3 \\
\end{array}$ & 41.9 & 0 & 0 & 13 & $\begin{array}{c}41 . \\
9\end{array}$ & \multirow{3}{*}{$\begin{array}{l}0.0 \\
01\end{array}$} \\
\hline 2 & Cukup & 6 & 19.3 & 6 & $\begin{array}{c}19 . \\
3\end{array}$ & 12 & $\begin{array}{c}38 . \\
6\end{array}$ & \\
\hline 3 & Baik & 2 & 6.5 & 4 & 13 & 6 & $\begin{array}{c}19 . \\
5\end{array}$ & \\
\hline & Total & $\begin{array}{l}2 \\
1\end{array}$ & 67.7 & 10 & $\begin{array}{c}32 . \\
\mathbf{3}\end{array}$ & 31 & 100 & \\
\hline
\end{tabular}


Tabel 16 menunjukkan hasil uji statistik tentang pengaruh pengetahuan petugas rekam medis dengan ketidaktepatan kode pada persalinan sectio caesarea. Diperoleh $\mathrm{p}=0.001<0.05$ sehingga Ho ditolak artinya ada hubungan antara pengetahuan petugas rekam medis dengan ketidaktepatan kode pada persalinan sectio caesarea di RSU IPI.

Tabel 18. Hubungan Faktor Sikap dengan Ketidaktepatan Kode Pada Persalinan Sectio Caesarea di RSU IPI Medan

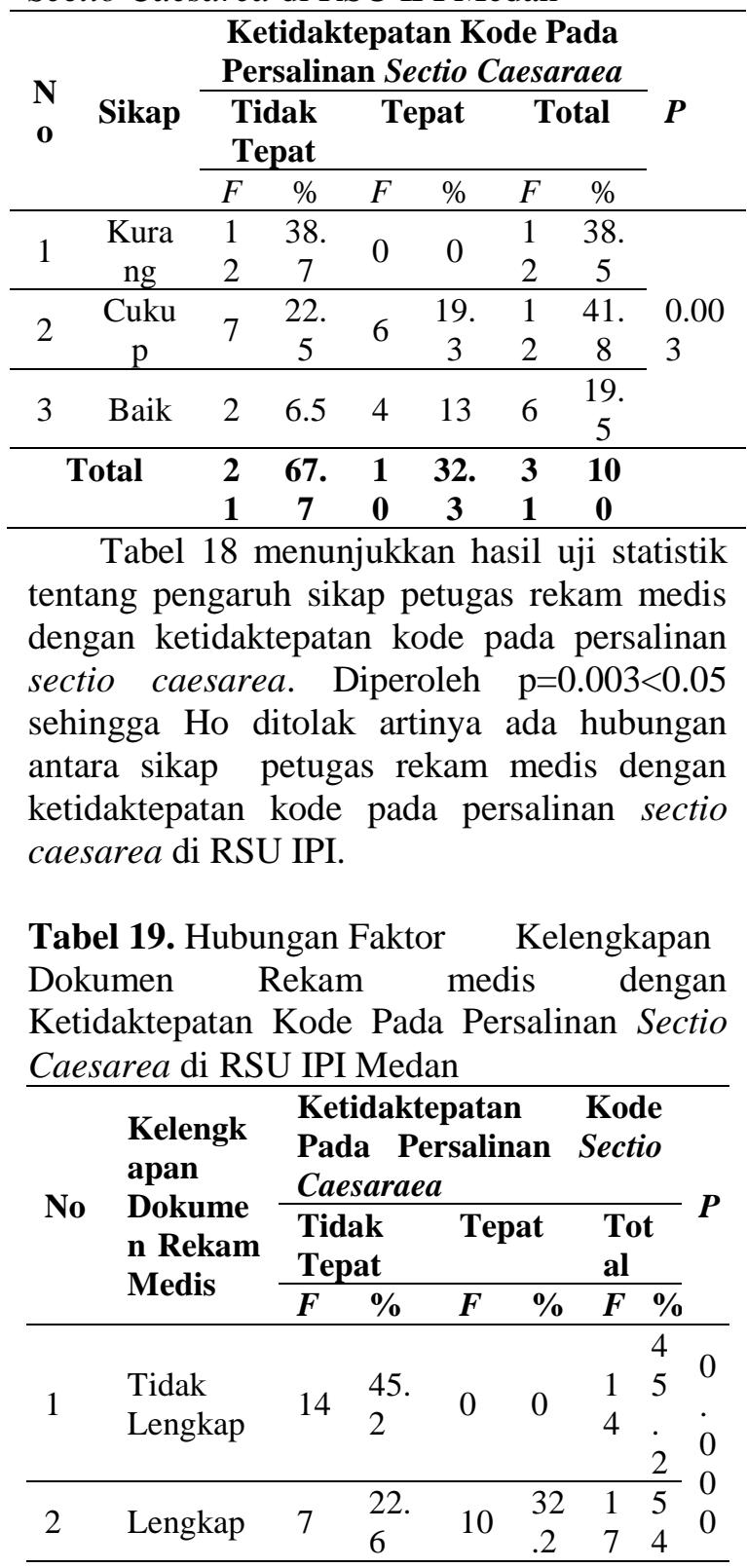

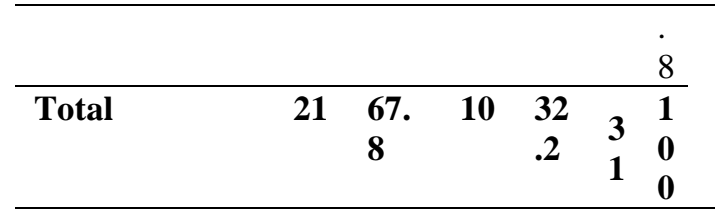

Tabel 19 menunjukkan hasil uji statistik tentang pengaruh kelengkapan dokumen rekam medis dengan ketidaktepatan kode pada persalinan sectio caesarea. Diperoleh $\mathrm{p}=0.000<0.05$ sehingga Ho ditolak artinya ada hubungan antara kelengkapan dokumen rekam medis dengan ketidaktepatan kode pada persalinan sectio caesarea di RSU IPI.

Tabel 20. Hubungan Faktor Sarana dan Prasarana dengan Ketidaktepatan Kode Pada Persalinan Sectio Caesarea di RSU IPI Medan

\begin{tabular}{|c|c|c|c|c|c|c|c|}
\hline \multirow{3}{*}{ No } & \multirow{3}{*}{$\begin{array}{c}\text { Sarana } \\
\text { dan } \\
\text { Prasara } \\
\text { na }\end{array}$} & \multicolumn{6}{|c|}{$\begin{array}{c}\text { Ketidaktepatan Kode Pada } \\
\text { Persalinan Sectio } \\
\text { Caesaraea }\end{array}$} \\
\hline & & \multicolumn{2}{|c|}{$\begin{array}{l}\text { Tidak } \\
\text { Tepat }\end{array}$} & \multicolumn{2}{|c|}{ Tepat } & \multicolumn{2}{|c|}{ Total } \\
\hline & & $F$ & $\%$ & $F$ & $\%$ & $\boldsymbol{F}$ & $\%$ \\
\hline 1 & $\begin{array}{c}\text { Tidak } \\
\text { Lengkap }\end{array}$ & 13 & 42 & 0 & 0 & 13 & 42 \\
\hline 2 & Lengkap & 8 & $\begin{array}{c}25 \\
.8\end{array}$ & 10 & $\begin{array}{l}32 \\
.2\end{array}$ & 17 & 58 \\
\hline & Total & 21 & $\begin{array}{l}67 \\
.8\end{array}$ & 10 & $\begin{array}{l}32 \\
.2\end{array}$ & 31 & $\begin{array}{c}10 \\
0\end{array}$ \\
\hline
\end{tabular}

Tabel 20 menunjukkan hasil uji statistik tentang pengaruh sarana dan prasarana dengan ketidaktepatan kode pada persalinan sectio caesarea. Diperoleh $\mathrm{p}=0.001<0.05$ sehingga Ho ditolak artinya ada hubungan antara sarana dan prasarana dengan ketidaktepatan kode pada persalinan sectio caesarea di RSU IPI.

\section{PEMBAHASAN}

Dari hasil penelitian berdasarkan distribusi pelatihan petugas rekam medis dari 31 responden yang telah diteliti, petugas rekam medis yang tidak ada mengikuti pelatihan lebih banyak dari petugas rekam medis yang ada mengikuti pelatihan. Petugas rekam medis yang tidak ada mengikuti pelatihan sebanyak 18 responden $(58.1 \%)$, dan yang ada mengikuti pelatihan sebanyak 13 responden (41.9\%). Sedangkan jika dilihat 
dari hubungan pelatihan petugas rekam medis dengan ketidaktepatan kode pada persalinan sectio caesarea. Diperoleh $\mathrm{p}=0.006<0.05$ sehingga Ho ditolak artinya ada hubungan antara pelatihan petugas rekam medis dengan ketidaktepatan kode pada persalinan sectio caesarea di RSU IPI.

Dari hasil penelitian berdasarkan distribu si pengetahuan petugas rekam medis dari 31 responden yang telah diteliti, petugas rekam medis yang berpengetahuan kurang lebih banyak dari petugas rekam medis yang berpengetahuan baik. Petugas rekam medis yang berpengetahuan kurang sebanyak 13 responden (41.9\%), dan petugas yang berpengetahuan baik sebanyak 6 responden (19.4\%). Sedangkan jika dilihat dari hubungan pengetahuan petugas rekam medis dengan ketidaktepatan kode pada persalinan sectio caesarea. Diperoleh $\mathrm{p}=0.001<0.05$ sehingga Ho ditolak artinya ada hubungan antara pengetahuan petugas rekam medis dengan ketidaktepatan kode pada persalinan sectio caesarea di RSU IPI.

Berdasarkan asumsi peneliti ditemukan adanya hubungan antara pengetahuan petugas rekam medis dengan ketidaktepatan kode pada persalinan sectio caesarea di RSU IPI. Hasil penelitian ini sejalan dengan Lily (2014) pada Beberapa Rumah Sakit di Jakarta yang menyatakan adanya hubungan yang signifikan antara akurasi koding dengan pengetahuan, koder yang berpengetahuan baik dapat mengkode secara akurat. Berdasarkan hasil penelitian ifalahma (2013) pada Pasien Rawat Inap Jaminan Kesehatan Masyarakat Berdasarkan ICD-10 di RSUD Simo Boyolali pengetahuan petugas pemberi kode diagnosis mempunyai hubungan yang signifikan dengan keakuratan kode diagnosis pasien rawat inap jamkesmas berdasarkan ICD-10.

Dari hasil penelitian berdasarkan distribu si Sikap petugas rekam medis dari 31 responden yang telah diteliti, petugas rekam medis yang bersikap cukup lebih banyak dari petugas rekam medis yang bersikap baik. Petugas rekam medis yang bersikap cukup sebanyak 13 responden (41.9\%), dan petugas yang bersikap baik sebanyak 6 responden (19.4\%). Sedangkan jika dilihat dari hubungan sikap petugas rekam medis dengan ketidaktepatan kode pada persalinan sectio caesarea. Diperoleh $\mathrm{p}=0.003<0.05$ sehingga Ho ditolak artinya ada hubungan antara sikap petugas rekam medis dengan ketidaktepatan kode pada persalinan sectio caesarea di RSU IPI.

Kelengkapan pengisian informasi dokumen rekam medis sangat berpengaruh terhadap keakuratan kode diagnosis. Dari hasil penelitian berdasarkan distribusi kelengkapan dokumen rekam medis dari 31 responden yang telah diteliti, dokumen rekam medis yang lengkap lebih banyak dari dokumen rekam medis yang tidak lengkap. Dokumen rekam medis yang lengkap sebanyak 17 berkas (54.8\%), dan dokumen rekam medis yang tidak lengkap sebanyak 14 berkas (45.2\%). Sedangkan jika dilihat dari hubungan kelengkapan dokumen rekam medis dengan ketidaktepatan kode pada persalinan sectio caesarea. Diperoleh $\mathrm{p}=0.000<0.05$ sehingga Ho ditolak artinya ada hubungan antara kelengkapan dokumen rekam medis dengan ketidaktepatan kode pada persalinan sectio caesarea di RSU IPI. Hasil penelitian ini sejalan dengan Pujihastuti (2013) Hubungan Kelengkapan Informasi Dengan Keakuratan Kode Diagnosis dan Tindakan Pada Dokumen Rekam Medis Rawat Inap didapat ada hubungan antara kelengkapan informasi dengan keakuratan kode diagnosis.

Sesuai dengan standar pelayanan rekam medis, maka fasilitas dan peralatan yang cukup harus disediakan guna tercapainya pelayanan yang efisien. Dalam pengelolaan rekam medis rumah sakit di indonesia. Dari hasil penelitian berdasarkan distribusi sarana dan prasarana dari 31 responden yang telah diteliti, sarana dan prasarana yang lengkap lebih banyak dari sarana dan prasarana yang tidak lengkap. Sarana dan prasarana yang lengkap sebanyak 18 berkas $(58.1 \%)$, dan sarana prasarana yang tidak lengkap sebanyak 13 berkas (41.9\%). Sedangkan jika dilihat dari hubungan sarana dan prasarana dengan 
ketidaktepatan kode pada persalinan sectio caesarea. Diperoleh $\mathrm{p}=0.001<0.05$ sehingga Ho ditolak artinya ada hubungan antara sarana dan prasarana dengan ketidaktepatan kode pada persalinan sectio caesarea di RSU IPI.

\section{KESIMPULAN}

Adapun kesimpulan yang dapat diambil dari penelitian ini:

1. Tidak ada hubungan antara umur petugas rekam medis dengan ketidaktepatan kode pada persalinan sectio caesarea di RSU IPI dengan nilai $\mathrm{p}=1>0.05$.

2. Tidak ada hubungan antara jenis kelamin petugas rekam medis dengan ketidaktepatan kode pada persalinan sectio caesarea di RSU IPI dengan nilai $\mathrm{p}=0.685>0.05$.

3. Ada hubungan antara pelatihan petugas rekam medis dengan ketidaktepatan kode pada persalinan sectio caesarea di RSU IPI dengan nilai $\mathrm{p}=0.006<0.05$.

4. Tidak ada hubungan antara pendidikan petugas rekam medis dengan ketidaktepatan kode pada persalinan sectio caesarea di RSU IPI dengan nilai $\mathrm{p}=0.1 .06>0.05$.

5. Tidak ada hubungan antara pengalaman petugas rekam medis dengan ketidaktepatan kode pada persalinan sectio caesarea di RSU IPI dengan nilai $\mathrm{p}=0.326>0.05$.

6. Ada hubungan antara pengetahuan petugas rekam medis dengan ketidaktepatan kode pada persalinan sectio caesarea di RSU IPI dengan nilaii $\mathrm{p}=0.001<0.05$.

7. Ada hubungan antara sikap petugas rekam medis dengan ketidaktepatan kode pada persalinan sectio caesarea di RSU IPI dengan nilai $\mathrm{p}=0.003<0.05$.

8. Ada hubungan antara kelengkapan dokumen rekam medis dengan ketidaktepatan kode pada persalinan sectio caesarea di RSU IPI dengan nilai $\mathrm{p}=0.000<0.05$.
9. Ada hubungan antara sarana dan prasarana dengan ketidaktepatan kode pada persalinan sectio caesarea di RSU IPI dengan nilai $\mathrm{p}=0.001<0.05$.

\section{SARAN}

Berdasarkan pembahasan dan kesimpulan tentang faktor-faktor yang mempengaruhi keetidaktepatan kode pada persalinan sectio caesarea di RSU IPI, maka peneliti menyarankan:

1. Rumah sakit memberi kesempatan para petugas rekam medis untuk mengikuti pelatihan koding secara berkesinambungan.

2. Perlu adanya peningkatan kualitas sumber daya manusia

3. Meningkatkan evaluasi di bagian kelengkapan dokumen rekam medis dengan membuat kebijakan agar dapat lebih terkontrol dan menghasilkan rekam medis yang berkualitas

\section{DAFTAR PUSTAKA}

.Lily W dan Rumana N.A. 2014. FaktorFaktor Yang Mempengaruhi Keakurasian koding Ibu Melahirkan dan Bayi di Beberapa Rumah Sakit. Jakarta: Universitas Esa Unggul.

Anggraini M, [et.al]. (2017). Bahan Ajar Rekam Medis dan informasi Kesehatan (RMIK) Klasifikasi Kodefikasi Penyakit dan Masalah Terkait I. Jakarta: Kementrian Kesehatan Republik Indonesia.

Arsinah, Shinta S.P. [et.al]. (2010). Asuhan Kebidanan Masa Persalinan. Yogyakarta : Graha Ilmu.

Benson, Ralph C, [et.al]. (2009). Buku Saku Obstetri dan Ginekologi. Jakarta: EGC.

Dep.Kesehatan RI. 2014. Peraturan Mentri Kesehatan RI No. 56 Tahun 2014. Klasifikasi dan Perizinan Rumah Sakit. Jakarta: Kemenkes RI.

Hatta, Gemala R. (2012). Pedoman Manajemen Informasi Kesehatan disarana. s.l: s.n. 
Hatta, Gemala R. (2014). Pedoman Manajeme $n$ Informasi Kesehatan disarana Pelayan an Kesehatan. Jakarta: Universitas Indon esia (UI-Press).

Ifalahma, Darah. (2013). Hubungan Pengetahuan Coder Dengan Keakuratan Kode Diagnosis Pasien Rawat Inap Jaminan Kesehatan Masyarakat Berdasarkan ICD-10 di RSUD Simo Boyolali. Surakarta: Apikes Citra Medika Surakarta.

Kementrian Kesehatan RI, (2013). Peraturan Mentri Kesehatan RI No. 55 Tahun 2013. Penyelenggaraan Pekerjaan Perekam Medis. Jakarta: Kemenkes RI.

Notoatmodjo, Soekidjo. (2009). Pengembanga n Sumber Daya Manusia. Jakarta: Rineka Cipta.

Notoatmodjo, Soekidjo. (2012). Metodologi Penelitiansehatan. Jakarta: Rineka Cipta. Pelayanan Kesehatan. Jakarta: Universitas Indonesia (UI-Press).

Pujihastuti A dan Sudra R.I. (2013). Hubungan Kelengkapan Informasi dengan Keakuratan Kode Diagnosis dan Tindakan Pada Dokumen Rekam Medis
Rawat Inap. Karanganyar: Apikes Mitra Husada Karanganyar.

Rasjidi, Imam. (2009). Manual Seksio Caesar ea \& Laparotomi Kelainan Adneksa. Jakarta: CV Agung Seto.

Ritonga R. (2017). Tinjauan Ketepatan Kode Diagnosa Pada Persalinan Sectio Caesarea di Rumah Sakit Umum Imelda Pekerja Indonesia. KTI APIKES imelda. Medan: APIKES Imelda

Rustiyanto, Ery. (2009). Etika Perekam Medis dan Sistem informasi Kesehatan. Yogyakarta: Graha Ilmu.

Saryono dan Mekar S.A. (2013). Metodologi Penelitian Kualitatif dan Kuntitatif Dalam Bidang Kesehatan. Yogyakarta: Nuha Medika

Simkin, Penny. (2008). Panduan Lengkap Kehamilan Melahirkan \& Bayi. Jakarta: Arcan

Wiknjosastro, H. (2007). Ilmu Bedah Kebidan an. Jakarta: Yayasan Bina Pustaka Sarwo no Prawirohardjo.

World Health Organization. (2010). Internati onal Statistical Classification of Diseases and Related Health Problems. USA: Gen eva 